\title{
ЕФЕКТИВНІСТЬ ПРОФІЛАКТИЧНОГО КОМПЛЕКСУ ПРИ КАРІЄСІ ЗА УМОВ СТАТЕВОГО ДОЗРІВАННЯ: ЕКСПЕРИМЕНТАЛЬНЕ ДОСЛІДЖЕННЯ
}

Вступ. Карієс є найпоширенішою у світі патологією, яка суттєво впливає не лише на стоматологічне, але й на соматичне здоров'я.

Мета дослідження - оцінити ефрективність профрілактичного комплексу при карієсі за умов статевого дозрівання в щурів-самців лінії Вістар.

Методи дослідження. Експеримент проведено на базі віварію Інституту стоматології НАМН України на 40 білих щурах лінії Вістар стадного розведення (самці, вік - 1 місяць, маса - 53-68 г). Тварин було поділено на 4 групи по 10 щурів у кожній: 1-ша - інтактний контроль на дієті віварію; 2-га - карієсогенний раціон; 3-тя - карієсогенний раціон+NaNO, 250 мг/л; 4-та - карієсогенний раціон+NaNO + +профрілактичний комплекс. Профрілактичний комплекс складався з препаратів, які вводили внутрішньошлунково щодня: “Кверцетин-гранули з пектином" 500 мг/кг та комплекс вітамінів і мінералів “Алфавіт школяр" по 150 мг/ка. Уранці тваринам проводили чистку зубів пастою R.O.C.S., у кінці дня - аплікації на зуби гелем R.O.C.S.

Результати й обговорення. Утримування молодих щурів на раціоні Стефрана призвело до гальмування приросту маси тіла тварин, розвитку каріозного процесу, інтенсифікації процесів запалення в порожнині рота й організмі, що супроводжувались активацією резорбційних процесів у твердих тканинах зубів та кістковій тканині щелеп на тлі зниження неспецифічного антимікробного захисту в порожнині рота і пульпі зубів тварин. Тривале споживання питної води, що містила 5 ГДК нітратів, у поєднанні 3 карієсогенним раціоном викликало посилення вищеописаних процесів у щурів. Крім того, у тварин з додатковим навантаженням нітратами встановлено збільшення ступеня атрофрії альвеолярної кістки нижньої щелепи, уповільнення синтетичних процесів у пульпі й кістковій тканині щелепи, зниження рівня кальцію в щелепах і підвищення "печінкових" маркерів у сироватці крові. Проведення щоденної профрілактики кверцетином з пектином, комплексом вітамінів і мінералів у поєднанні з гігієною засобами для порожнини рота R.O.C.S. есрективно запобігало негативній дії карієсогенного раціону та нітратів.

Висновок. За експериментальних умов підтверджено ефрективність профрілактичного комплексу для нівелювання несприятливих карієсогенних впливів.

КЛЮчОВІ СЛОВА: карієс; статеве дозрівання; профілактика; біохімічні маркери.

ВСТУП. Стоматологічне здоров'я може впливати на функціональні, психологічні та соціальні аспекти самопочуття дитини [1, 2]. Наявність болю або дискомфорту, зумовленого стоматологічними захворюваннями, негативно впливає на розвиток дитини, погіршує сон, фрізичний розвиток, може викликати поведінкові проблеми та впливати на академічну успішність. Крім того, поганий стан стоматологічного здоров'я може ускладнювати спілкування, соціалізацію дитини, призводячи до зниження її самооцінки і втрати мотивації до навчання і позашкільної активності.

За даними західних фахівців, більшість випадків стоматологічних захворювань у дітей пов'язана 3 незадовільним рівнем самозберігальної поведінки в родині, недоліками особистої (с) О. А. Макаренко, М. І. Веліков, 2020. гігієни [1, 3-5]. У деяких регіонах з високим антропогенним навантаженням на стан стоматологічного здоров'я може впливати наявність ксенобіотиків у питній воді, атмосферному повітрі й продуктах харчування [6-8]. Крім того, певний вплив на фрормування емалі та загальний фрункціональний стан тканин порожнини рота має несприятливий мінеральний склад питних вод у так званих еколого-гігієнічних провінціях [9]. Також існують дані, що пов'язують захворювання порожнини рота з такими станами, як мала маса тіла при народженні [8], передчасні пологи [3] та дефіцит заліза [5].

За даними Центру контролю та профрілактики захворювань США, карієс є найпоширенішим хронічним дитячим захворюванням, що трапляється в 5 разів частіше, ніж астма, в дітей віком 
від 5 до 17 років. У Канаді 57 \% дітей віком від 6 до 11 років мають карієс [10]. За оцінками експертів ВООЗ, у світі від карієсу страждають $90 \%$ дітей шкільного віку, причому найбільш несприятлива епідеміологічна ситуація за цим захворюванням склалася у країнах, що розвиваються $[3,5]$. На жаль, ураженість дитячого населення України карієсом є вищою, ніж в інших країнах Європейського регіону $[9,11]$. У той час як у розвинутих країнах спостерігають виражену тенденцію до зменшення частоти каріозних уражень i, відповідно, ускладнень карієсу, українські фрахівці досі мають справу зі справжньою епідемією карієсу [9]. Це пов'язано з особливостями структури харчування, рівнем гігієнічних навичок, ефективністю санаційних заходів, у тому числі фрторопрофрілактики.

За даними соціально-гігієнічного моніторингу, основними чинниками ризику для виникнення карієсу в населених пунктах Придунав'я були неоптимальний сольовий склад питних вод та надлишок рафрінованих вуглеводнів у раціоні харчування. За останні роки запропоновано чимало профрілактичних комплексів для запобігання карієсу в дітей, однак жодний з них не адаптований під специфріку регіону.

Мета дослідження - оцінити есрективність профрілактичного комплексу при карієсі за умов статевого дозрівання в щурів-самців лінії Вістар.

МЕТОДИ ДОСЛІДЖЕННЯ. Експеримент проведено на базі віварію Інституту стоматології НАМН України на 40 білих щурах лінії Вістар стадного розведення (самці, вік - 1 місяць, маса тіла - 53-68 г). Тварин було поділено на 4 групи по 10 щурів у кожній: 1-ша - інтактний контроль на дієті віварію; 2-га - карієсогенний раціон; 3-тя - карієсогенний раціон+NaNO 4-та - карієсогенний раціон+NaNO${ }_{3}+$ профрілактичний комплекс.

Експериментальну патологію карієсу викликали шляхом переведення 30 щурів на карієсогенний раціон Стесрана [11-13]. Нітрат натрію $\left(\mathrm{NaNO}_{3}\right)$ вводили тваринам 3-ї і 4-ї груп з питною водою, що містила 5 гдК нітрату - $250 \mathrm{mг/л.}$ Профрілактичний комплекс складався 3 препаратів, які вводили внутрішньошлунково щодня: "Кверцетин-гранули з пектином" 500 мг/кг (ПАТ НВЦ “Борщагівський ХФЗ”, Україна) та комплекс вітамінів і мінералів "Алфравіт школяр" по 150 мг/кг (виробник "Вітаміни ОАО", Україна). Уранці тваринам проводили чистку зубів пастою R.O.C.S. (ТОВ “ЕвроКосМед”, Росія), в кінці дня - аплікації на зуби гелем R.O.C.S. Профрілактику препаратами почали проводити з першого дня переведення щурів на карієсогенний раціон. Тварин зважували на початку і в кінці експерименту.
Тривалість досліду становила 32 дні. Після його закінчення у тварин під тіопенталовим наркозом (20 мг/кг) і пілокарпіновою стимуляцією (підшкірно 5 мг/кг) збирали ротову рідину. Виводили щурів з експерименту шляхом тотального кровопускання із серця. Збирали кров для отримання сироватки, виділяли блоки щелеп із зубами, пульпу.

У зубах оцінювали глибину ураження карієсом, кількість каріозних порожнин, середнє на одного щура [11]. Ступінь атрофії альвеолярного відростка визначали за методом Ніколаєвої [13].

У ротовій рідині визначали активність лізоциму бактеріолітичним методом за посвітлінням субстрату Micrococcus lysodeicticus ("Sigma", США) [13], активність еластази - за гідролізом субстрату BOC-L-alanine-4-nitrophenyl ("Sigma", США) [14], активність кислої фросфратази - за гідролізом паранітрофренілфоосфату ("Sigma", Велика Британія) при рН 4,8 [13, 14].

У сироватці крові визначали активність еластази, кислої (pH 4,8) та лужної (pH 10,5) фосоратаз $[12,13]$. У пульпі визначали активність лізоциму, кислої та лужної фоссратаз [13]. У кістковій тканині щелеп визначали активність еластази, кислої та лужної фоссратаз, вміст кальцію оцінювали за допомогою арсеназного реагенту і фоссфору - за відновленням фросфорорно-молібденової кислоти [13-15].

Статистичну обробку отриманих результатів проводили з використанням t-критерію Стьюдента [13].

РЕЗУЛЬТАТИЙ ОБГОВОРЕННЯ. У ТабЛИЦі 1 наведено результати визначення приросту маси тіла експериментальних тварин за 32 дні. Утримування щурів на карієсогенному раціоні призвело до затримки приросту маси тіла тварин на $28,6 \%$. У щурів 3-ї групи, які отримували додатково до карієсогенного раціону 5 ГДК нітратів, приріст маси тіла зменшився на 47,6 \% порівняно 3 інтактними тваринами і на 26,5 \% щодо відповідного показника в 2-й групі. Усі встановлені значення низького приросту маси тіла щурів достовірно значимі ( $<<0,02-0,05$, табл. 1). Проведення профрілактики ефективно попереджувало зниження приросту маси тіла тварин 4-ї групи - показник був достовірно вищим від значень щурів 3-ї групи $\left(p_{2}<0,05\right)$ і не відрізнявся від рівня інтактних тварин ( $>>0,1$, табл.1).

Результати, узагальнені в таблиці 2, свідчать про збільшення кількості каріозних порожнин у зубах щурів 2-ї групи під впливом раціону Стефрана майже у 2 рази ( $<<0,002), 3$ додатковим введенням нітратів - у 2,7 раза $\left(p<0,001, p_{1}<0,05\right)$. Профрілактичний комплекс, який вводили 
Таблиця 1 - Приріст маси тіла експериментальних тварин

\begin{tabular}{|c|c|c|c|}
\hline \multirow[b]{2}{*}{ Група щурів } & \multicolumn{2}{|c|}{ Маса тіла } & \multirow{2}{*}{$\begin{array}{c}\text { Приріст } \\
\text { маси тіла }\end{array}$} \\
\hline & $\begin{array}{c}\text { початок } \\
\text { експерименту }\end{array}$ & $\begin{array}{c}\text { закінчення } \\
\text { експерименту }\end{array}$ & \\
\hline Інтактний контроль & $60,5 \pm 8,4$ & $149,2 \pm 15,2$ & $88,7 \pm 9,4$ \\
\hline Карієсогенний раціон & $59,7 \pm 8,1$ & $123,0 \pm 11,9$ & $\begin{array}{l}63,3 \pm 5,3 \\
p<0,02\end{array}$ \\
\hline Карієсогенний раціон+NaNO, 250 мг/л & $53,7 \pm 6,4$ & $100,2 \pm 9,7$ & $\begin{array}{l}46,5 \pm 5,9 \\
p<0,002 \\
p_{1}<0,05\end{array}$ \\
\hline $\begin{array}{l}\text { Карієсогенний раціон+NaNO }+ \text { +профрілактичний } \\
\text { комплекс }\end{array}$ & $59,3 \pm 8,2$ & $127,7 \pm 15,1$ & $\begin{array}{c}68,4 \pm 8,6 \\
\mathrm{p}>0,1 \\
\mathrm{p}_{1}>0,6 \\
\mathrm{p}_{2}<0,05\end{array}$ \\
\hline
\end{tabular}

Примітка. Тут і в таблицях 2, 3: p - достовірність відмінностей від показника в групі “інтактний контроль”; р $_{1}-$ достовірність відмінностей від показника в групі "карієсогенний раціон”; $p_{2}$ - достовірність відмінностей від показника в групі “карієсогенний раціон+NaNO${ }_{3}$.

тваринам 4-ї групи, достовірно зменшував кількість каріозних уражень до нормальних значень ( $>>0,4$, табл. 2).

Поряд з інтенсифрікацією каріозного процесу в щурів 2-ї та 3-ї груп збільшувалася і його тяжкість - глибина порожнин зростала на 50,0 та 126,3 \% відповідно. Застосування кверцетину, комплексу вітамінів і мінералів у поєднанні 3 місцевим використанням засобів R.O.C.S. запобігало збільшенню глибини каріозних уражень $(p>0,4)$.

Ступінь атрофії альвеолярного відростка нижньої щелепи достовірно збільшився на 21,8 \% тільки в щурів 3-ї групи, які одержували нітрати на тлі раціону Стефрана, щодо значень тварин 2-ї групи $\left(p_{1}<0,05\right)$. Проведення профрілактики не мало істотного впливу на досліджуваний показник ( $p>0,8, p_{1}>0,2, p_{2}>0,8$, табл. 2).

Таким чином, результати, наведені в таблиці 2, переконливо доводять карієспрофрілактичні властивості досліджуваного профрілактичного комплексу, який застосовують при карієсогенній дієті на тлі нітратного навантаження.
У таблиці 3 наведено результати дослідження маркерів запалення (активності еластази і кислої фросфратази) та фрактора неспецифрічного мікробного захисту (активності лізоциму) в ротовій рідині експериментальних тварин. Карієсогенний раціон сприяв зростанню активності еластази на 57,1 \%, а кислої фосфратази - на 68,8 \%. Одночасний вплив раціону Стефрана і нітратів призвів до більш значного підвищення цих маркерів: активності еластази - на 119,0\%, активності кислої фоссратази - на 156,3 \% відносно рівня інтактних тварин. Зростання маркерів запалення в ротовій рідині щурів 3-ї групи мало достовірний характер і порівняно з відповідними показниками тварин 2-ї групи $\left(p_{1}<0,02\right.$, $\mathrm{p}_{1}<0,02$, табл. 3). Підвищення маркерів запалення в ротовій рідині щурів, яких утримували в карієсогенних умовах на тлі нітратного навантаження, свідчило про розвиток запалення в порожнині рота тварин.

Профрілактичне введення кверцетину, вітамінів і мінералів у комплексі з гігієною порожнини рота засобами R.O.C.S. привело до нормалізації

Таблиця 2 - Вплив карієсогенного раціону, нітратів і профілактики на атрофрію альвеолярного відростка та розвиток карієсу зубів у щурів

\begin{tabular}{||l|c|c|c||}
\hline \multicolumn{1}{||}{ Група щурів } & $\begin{array}{c}\text { Кількість каріозних } \\
\text { порожнин, } \\
\text { середнє } \\
\text { на одного щура }\end{array}$ & $\begin{array}{c}\text { Глибина ураження } \\
\text { зубів карієсом, } \\
\text { бали }\end{array}$ & $\begin{array}{c}\text { Ступінь атрофії } \\
\text { альвеолярного } \\
\text { відростка нижньої } \\
\text { щелепи, \% }\end{array}$ \\
\hline Інтактний контроль & $3,6 \pm 0,5$ & $3,8 \pm 0,6$ & $16,8 \pm 1,3$ \\
\hline Карієсогенний раціон & $7,1 \pm 0,8$ & $5,7 \pm 0,4$ & $15,1 \pm 1,1$ \\
& $\mathrm{p}<0,002$ & $\mathrm{p}<0,02$ & $\mathrm{p}>0,3$ \\
\hline Карієсогенний & $9,7 \pm 0,8$ & $8,6 \pm 0,6$ & $\mathrm{p}>0,4$ \\
раціон+NaNO & $\mathrm{p}<0,001$ & $\mathrm{p}_{3}<0,001$ & $\mathrm{p}_{1}<0,05$ \\
\hline Карієсогеннй & $\mathrm{p}_{1}<0,05$ & $\mathrm{p}_{1}<0,001$ & $17,0 \pm 0,8$ \\
раціон+NaNO ${ }_{3}^{+}$ & $4,2 \pm 0,4$ & $4,5 \pm 0,4$ & $\mathrm{p}>0,8$ \\
просрілактичний комплекс & $\mathrm{p}>0,4$ & $\mathrm{p}>0,4$ & $\mathrm{p}_{1}>0,2$ \\
& $\mathrm{p}_{1}<0,002$ & $\mathrm{p}_{1}<0,05$ & $\mathrm{p}_{2}>0,8$ \\
\hline
\end{tabular}


Таблиця 3 - Вплив нітратів та профілактики на активність еластази, кислої фоссратази і лізоциму в ротовій рідині щурів, які отримували карієсогенний раціон

\begin{tabular}{|l|c|c|c||}
\hline \multicolumn{1}{|c|}{ Група щурів } & $\begin{array}{c}\text { Активність еластази, } \\
\text { мккат/л }\end{array}$ & $\begin{array}{c}\text { Активність кислої } \\
\text { фроссратази, мкат/л }\end{array}$ & $\begin{array}{c}\text { Активність } \\
\text { лізоциму, од./л }\end{array}$ \\
\hline Інтактний контроль & $0,21 \pm 0,03$ & $0,16 \pm 0,02$ & $209 \pm 18$ \\
\hline Карієсогенний раціон & $0,33 \pm 0,04$ & $0,27 \pm 0,04$ & $147 \pm 13$ \\
& $\mathrm{p}<0,02$ & $\mathrm{p}<0,02$ & $\mathrm{p}<0,02$ \\
\hline Карієсогенний раціон+NaNO & $0,46 \pm 0,03$ & $0,41 \pm 0,05$ & $94 \pm 7$ \\
& $\mathrm{p}<0,001$ & $\mathrm{p}<0,001$ & $\mathrm{p}<0,001$ \\
& $\mathrm{p}_{1}<0,02$ & $\mathrm{p}_{1}<0,02$ & $\mathrm{p}_{1}<0,002$ \\
\hline Карієсогенний раціон+NaNO ${ }_{3}+$ & $0,27 \pm 0,02$ & $0,19 \pm 0,02$ & $165 \pm 12$ \\
просрілактичний комплекс & $\mathrm{p}>0,1$ & $\mathrm{p}>0,5$ & $\mathrm{p}<0,05$ \\
& $\mathrm{p}_{1}>0,5$ & $\mathrm{p}_{1}<0,05$ & $\mathrm{p}_{1}>0,3$ \\
& $\mathrm{p}_{2}<0,001$ & $\mathrm{p}_{2}<0,001$ & $\mathrm{p}_{2}<0,001$ \\
\hline
\end{tabular}

обох маркерів запалення в ротовій рідині щурів, які отримували карієсогенний раціон у поєднанні 3 питною водою, що містила 5 ГДК нітратів ( $p>0,1, p>0,5$ відповідно, табл. 3).

Моделювання карієсу зубів призвело до достовірного зменшення в ротовій рідині активності лізоциму на 29,7 \%, а отже, і до зниження неспецифрічного антимікробного захисту порожнини рота щурів 2-ї групи. Додаткове споживання питної води з нітратами викликало ще більше зниження цього фрактора неспецифічного захисту - на 55,0 \%. Проведення запропонованої профрілактики запобігло зменшенню активності лізоциму в ротовій рідині щурів 4-ї групи $\left(p_{2}<0,001\right)$, але не підвищило до рівня в інтактних тварин ( $p<0,05)$.

Результати, наведені в таблиці 3, показали розвиток запалення з одночасним зниженням антимікробного захисту в порожнині рота щурів, які перебували в карієсогенних умовах, і посилення цих процесів при використанні питної води з 5 ГДК нітратів. Проведення запропонованої просрілактики ефрективно запобігло виникненню патології органів порожнини рота тварин.

Під час біохімічного аналізу кісткової тканини щелеп у щурів, які отримували карієсогенний раціон, було виявлено збільшення активності кислої фросфратази на 14,8 \% (p<0,01), еластази на 45,2 \% ( $<<0,002)$. Активність лужної фросоратази при цьому не змінилася ( $p>0,25)$. Отримані результати свідчать про метаболічні порушення в кістковій тканині - активацію процесів демінералізації і гідролізу колагенової матриці. Додаткове навантаження нітратами посилювало встановлені порушення мінерального обміну в кістковій тканині, оскільки ступінь підвищення активності ензимів у щелепах тварин 3-ї групи був більш вираженим: кислої фросфратази - на 88,3 \% $\left(p<0,001, p_{1}<0,02\right)$, еластази - на 101,6\% $\left(p<0,001, p_{1}<0,002\right)$. Крім того, в кістковій тканині щелеп щурів 3-ї групи достовірно знизилась активність лужної фроссратази - на 27,9 \%, що вказувало на пригнічення синтетичних процесів у кістковій тканині в результаті тривалого впливу нітратів ( $p<0,002)$.

Введення профрілактичних препаратів і гігієна порожнини рота засобами R.O.C.S. запобігли зниженню активності лужної фроссратази в кістковій тканині щелеп щурів 4-ї групи ( $p>0,5, p_{1}>0,6$, $\left.\mathrm{p}_{2}<0,05\right)$. Позитивний вплив мали профрілактичні курси на кислу фоосфатазу, активність якої достовірно не відрізнялася від показників у інтактних тварин ( $>>0,1)$. У кістковій тканині щелеп щурів 4-ї групи, які одержували профрілактичні препарати, активність еластази також була на рівні нормальних значень ( $p>0,3, p_{1}<0,01$, $\left.p_{2}<0,001\right)$.

Профрілактичне введення комплексу вітамінів, мінералів, кверцетину і пектину в поєднанні 3 місцевим застосуванням гігієнічних засобів R.O.C.S. сприяло збереженню рівня кальцію і $\mathrm{Ca} / \mathrm{P}$ у щелепах щурів 4-ї групи, показники яких відповідали значенням в інтактних тварин $(p>0,05)$.

ВИСНОВКИ. 1. Утримування молодих щурів на раціоні Стефана призводить до гальмування приросту маси тіла тварин, розвитку каріозного процесу, інтенсифікації процесів запалення в порожнині рота й організмі, що супроводжуються активацією резорбційних процесів у твердих тканинах зубів та кістковій тканині щелеп на тлі зниження неспециорічного антимікробного захисту в порожнині рота і пульпі зубів тварин.

2. Тривале споживання питної води, що містить 5 ГДК нітратів, у поєднанні з карієсогенним раціоном викликає посилення вищеописаних процесів у щурів. Крім того, у тварин 3 додатковим навантаженням нітратами встановлено збільшення ступеня атрофії альвеолярної кістки нижньої щелепи, уповільнення синтетичних процесів у пульпі й кістковій тканині щелепи, 
зниження рівня кальцію в щелепах і підвищення "печінкових" маркерів у сироватці крові.

3. Проведення щоденної профрілактики кверцетином з пектином, комплексом вітамінів і мінералів "Алфравіт школяр" у поєднанні $з$ гігієною засобами для порожнини рота R.O.C.S. есрек-

\section{СПИСОК ЛІТЕРАТУРИ}

1. Prevalence and caries-related risk factors in schoolchildren of 12- and 15-year-old: a cross-sectional study / N. Obregón-Rodríguez, P. Fernández-Riveiro, M. Piñeiro-Lamas [et al.] // BMC Oral Health. - 2019. 19 (1). -P. 120.

2. Stevens C. Children's oral health: 70 years on / C. Stevens // Br. Dent. J. - 2018. - 225 (2). - P. 96.

3. Indicators of risk for dental caries in children: A holistic approach / S. Fernando, S. K. Tadakamadla, M. Bakr [et al.] // JDR Clin. Trans. Res. - 2019. - 4 (4). P. 333-341.

4. Is the caregivers oral health related to dental caries in children or adolescents? A systematic review / M. G. Mattos, C. A. Fernandez, D. Masterson [et al.] // Clin. Oral Investig. - 2019. - 23 (10). - P. 3843-3854.

5 . The school social environment and oral healthrelated quality of life in children: a multilevel analysis / L. A. Pauli, M. B. Correa, F. F. Demarco, M. L. Goettems // Eur. J. Oral Sci. - 2020. - 128 (2). - P. 153-159.

6. Матчин А. А. Влияние экологических факторов на стоматологическое здоровье детского населения Оренбурга / А. А. Матчин, Н. П. Сетко, Е. С. Нефедова // Вестн. Оренбургского государственного университета. - 2013. - № 10 (159). - С. 12-16.

7. Шевченко О. В. Модель областной программы первичной профилактики основных стоматологических заболеваний / О. В. Шевченко // Стоматология детского возраста и профиилактика. - 2014. - 13, № 3 (50). - C. 8-11.

\section{REFERENCES}

1. Obregón-Rodríguez, N., Fernández-Riveiro, P., Piñeiro-Lamas. M., Smyth-Chamosa, E., Montes-Martínez, A., \& Suárez-Cunqueiro, M.M. (2019). Prevalence and caries-related risk factors in schoolchildren of 12- and 15-year-old: a cross-sectional study. BMC Oral Health., 19 (1), 120.

2. Stevens, C. (2018). Children's oral health: 70 years on. Br. Dent. J., 225 (2), 96.

3. Fernando, S., Tadakamadla, S.K., Bakr, M., Scuffham, P.A., \& Johnson, N.W. (2019). Indicators of risk for dental caries in children: A holistic approach. JDR Clin Trans Res., 4 (4), 333-341. тивно запобігає негативній дії карієсогенного раціону та нітратів.

Перспективи подальших досліджень можуть бути пов'язані з оцінкою клінічної ефективності апробованого в експерименті профрілактичного комплексу за умов рандомізованого клінічного дослідження.

8. Pinho JRO, Thomaz EBAF, Ribeiro CCC, Alves CMC, Silva AAMD. Factors associated with the development of dental defects acquired in the extrauterine environment. Braz Oral Res. 2019 Oct 10;33:e094.

9. Фтор у питних водах Одеської області: гігієнічне та клініко-прогностичне значення / Л. Г. Засипка, О.В.Деньга, О. М. Світлична, Ю. М. Ворохта // Вісн. стоматології. - 2010. - № 3. - С. 96-102.

10. Левицкий А. П. Методы экспериментальной стоматологии : учеб. пособ. / А. П. Левицкий, О. А. Макаренко, С. А. Демьяненко. - Симферополь, ООО "Изд-во Тарпан", 2018. - 78 с.

11. Bishop M. Clinical Chemistry: Principles, Techniques, Correlations 8th Edition Jones \& Bartlett Learning; 8 edition (February 4, 2017). -736 p.

12. Экспериментальные методы исследования стимуляторов остеогенеза : метод. рек. / [А. П. Левицкий, О. А. Макаренко, О. В. Деньга и др.]. - К. : ГФЦ, 2005. - 50 c.

13. Експериментальне вивчення токсичної дії та специфрічної ефективності засобів для догляду за порожниною рота : метод. рек. / [Т. П. Терешина, К. М. Косенко, А. П. Левицький та ін.]. - К. : ДФЦ МОЗ України, 2003. - С. 22-23.

14. Левицкий А. П. Лизоцим вместо антибиотиков / А. П. Левицкий. - Одесса : КП ОГТ, 2005. - 74 с.

15. Сернов Л. Н. Элементы экспериментальной фрармакологии / Л. Н. Сернов, В. В. Гацура. - М., 2000. - C. 117-119.

4. Mattos, M.G., Fernandez, C.A., Masterson, D., Maia, L.C., \& Neves, A.A. (2019). Is the caregivers oral health related to dental caries in children or adolescents? A systematic review. Clin. Oral. Investig., 23 (10), 38433854.

5. Pauli, L.A., Correa, M.B., Demarco, F.F., \& Goettems, M.L. (2020). The school social environment and oral health-related quality of life in children: a multilevel analysis. Eur. J. Oral Sci., 128 (2), 153-159.

6. Matchin, A.A., Setko, N.P., \& Nefedova, E.S. (2013). Vliyaniye ekologicheskikh faktorov na stomatologicheskoye zdorovye detskogo naseleniya Orenburga 
[Dental healthh of children in areas of various anthropogenic pollution]. Vestnik Orenburgskogo gosudarstvennogo universiteta - Bulletin of the Orenburg State University, 10 (159), 12-16 [in Russian].

7. Shevchenko, O.V. (2014). Model oblastnoy programmy pervichnoy profilaktiki osnovnykh stomatologicheskikh zabolevaniy [Model of the regional program of primary prevention of major dental diseases]. Stomatologiya detskogo vozrasta i profilaktika - Pediatric Dentistry and Prevention, 13, 3 (50), 8-11 [in Russian].

8. Pinho, J.R.O., Thomaz, E.B.A.F., Ribeiro, C.C.C., Alves, C.M.C., \& Silva, A.A.M.D. (2019). Factors associated with the development of dental defects acquired in the extrauterine environment. Braz. Oral Res., 33, e094.

9. Zasypka, L.H., Denha, O.V., Svitlychna, O.M., \& Vorokhta, Yu.M. (2010). Ftor u pytnykh vodakh Odeskoi oblasti: hihiienichne ta kliniko-prohnostychne znachennia [Fluoride in drinking waters of the Odesa region: hygienic and clinical prognostic value]. Visnyk stomatolohii Bulletin of Dentistry, 3, 96-102 [in Ukrainian].

10. Levitskiy, A.P., Makarenko, O.A., \& Demyanenko, S.A. (2018). Metody eksperimentalnoy stomatologii. Uchebnoye posobiye [Methods of experimental dentistry. Study guide]. Simferopol, OOO "Izd-vo Tarpan" [in Russian].
11. Bishop M. Clinical Chemistry: Principles, Techniques, Correlations 8th Edition. Jones \& Bartlett Learning; 8 edition.

12. Levitskiy, A.P., Makarenko, O.A., Denga, O.V., Sukmanskiy, O.I., Podorozhnaya, R.P., Rossakhanova, L.N., ..., \& Zelenina, Yu.V. (2005). Eksperimentalnyye metody issledovaniya stimulyatorov osteogeneza. Metodrekomendatsii [Experimental methods studies of osteogenesis stimulants. Method recommendations]. Kyiv: GFTs [in Russian].

13. Tereshyna, T.P., Kosenko, K.M., Levytskyi, A.P., Mozhova, N.V., \& Blyzniuk, H.O. (2003). Metodychni rekomendatsii. Eksperymentalne vyvchennia toksychnoi dii ta spetsyfichnoi efektyvnosti zasobiv dlia dohliadu za porozhnynoiu rota [Methodical recommendations. Experimental study of toxic effects and specific efficacy of oral care products]. Kyiv: DFTS MOZ Ukrainy [in Ukrainian].

14. Levitskiy, A.P. (2005). Lizotsim vmesto antibiotikov [Lysozyme instead of antibiotics]. Odesa: KP OGT [in Russian].

15. Sernov, L.N., \& Gatsura, V.V. (2000). Elementy eksperimentalnoy farmakologii [Elements of experimental pharmacology]. Moscow [in Russian].

\section{ЭФФЕКТИВНОСТЬ ПРОФИЛАКТИЧЕСКОГО КОМПЛЕКСА ПРИ КАРИЕСЕ В УСЛОВИЯХ ПОЛОВОГО СОЗРЕВАНИЯ: ЭКСПЕРИМЕНТАЛЬНОЕ ИССЛЕДОВАНИЕ}

\section{Резюме}

Вступление. Кариес является самой распространенной в мире патологией, которая существенно влияет не только на стоматологическое, но и на соматическое здоровье.

Цель исследования - оценить эфффективность профилактического комплекса при кариесе в условиях полового созревания у крыс-самцов линии Вистар.

Методы исследования. Эксперимент проведен на базе вивария Института стоматологии НАМН Украины на 40 белых крысах линии Вистар стадного разведения (самцы, возраст - 1 месяц, масса - 53-68 г). Животные были разделены на 4 группы по 10 крыс в каждой: 1-я - интактный контроль на диете вивария; 2-я - кариесогенный рацион; 3-я - кариесогенный рацион+NaNO , 250 мг/л; 4-я - кариесогенный рацион+NaNO+ +профрилактический комплекс. Профрилактический комплекс состоял из препаратов, которые вводили внутрижелудочно ежедневно: "Кверцетин-гранулы с пектином" 500 мг/кг и комплекс витаминов и минералов "Алфавит школьник" по 150 мг/ке. Утром животным проводили чистку зубов пастой R.O.C.S., в конце дня - аппликации на зубы гелем R.O.C.S.

Результаты и обсуждение. Содержание молодых крыс на рационе Стефрана привело к торможению прироста массы тела животных, развитию кариозного процесса, интенсификации процессов воспаления в полости рта и организме, которые сопровождались активацией резорбционных процессов в твердых тканях зубов и костной ткани челюстей на фроне снижения неспецифической антимикробной защиты в полости рта и пульпе зубов животных. Длительное потребление питьевой воды, содержащей 5 пДК нитратов, в сочетании с кариесогенным рационом вызвало усиление вышеописанных процессов у крыс. Кроме того, у животных с дополнительной нагрузкой нитратами установлено увеличение степени атрофии альвеолярной кости нижней челюсти, замедление синтетических процессов в пульпе и костной ткани челюсти, снижение уровня кальция в челюстях и повышение “печеночных" маркеров в сыворотке 
крови. Проведение ежедневной профилактики кверцетином с пектином, комплексом витаминов и минералов в сочетании с гигиеной средствами для полости pта R.O.C.S. эфрфективно предотвращало негативное воздействие кариесогенного рациона и нитратов.

Вывод. В экспериментальных условиях подтверждена эффрективность профилактического комплекса для нивелирования неблагоприятных кариесогенных воздействий.

КЛЮЧЕВЫЕ СЛОВА: кариес; половое созревание; профилактика; биохимические маркеры.

O. A. Makarenko, M. I. Velikov INSTITUTE OF DENTISTRY AMS OF UKRAINE, ODESA

\title{
THE EFFECTIVENESS OF THE PROPHYLACTIC COMPLEX IN CARIES DURING PUBERTY: AN EXPERIMENTAL STUDY
}

\begin{abstract}
Summary
Introduction. Caries is the most common pathology in the world, which significantly affects not only dental but also somatic health.

The aim of the study - to evaluate the effectiveness of the preventive complex for caries under puberty in Wistar rats.

Research Methods. The experiment was conducted on the basis of the vivarium of the State University "IS NAMNU" on 40 white rats of the Wistar herd breeding line (males, 1 month old, weight 53-68 g). The animals were divided into 4 groups, 10 rats each: group 1 - intact control on a vivarium diet; group 2 - cariogenic diet; group 3 cariogenic diet $+\mathrm{NaNO}_{3} 250 \mathrm{mg} /$; group 4 - cariogenic diet $+\mathrm{NaNO}_{3}+$ prophylactic complex. The preventive complex consisted of preparations administered intragastrically daily: "Quercetin granules with pectin" $500 \mathrm{mg} / \mathrm{kg}$ and a complex of vitamins and minerals "Alphabet schoolboy" $150 \mathrm{mg} / \mathrm{kg}$. In the morning, the rats were brushed with R.O.C.S. paste, and at the end of the day, ROCS gel applications on the teeth were administrated.

Results and Discussion. The content of young rats on Stefan's diet led to inhibition of the increase in body weight of animals, the development of the carious process, the intensification of inflammation in the oral cavity and the body, accompanied by the activation of resorption processes in the hard tissues of the teeth and bone tissue of the jaw against the background of a decrease in non-specific antimicrobial protection in the oral cavity and pulp animal teeth. Long-term consumption of drinking water containing 5 MPC nitrates, in combination with a cariogenic diet, intensified the above processes in rats. In addition, in animals with an additional nitrate load, an increase in the degree of atrophy of the alveolar bone of the lower jaw, a slowdown in the synthetic processes in the pulp and bone tissue of the jaw, a decrease in the level of calcium in the jaws, and an increase in "liver" markers in the blood serum were found. Conducting daily prophylaxis with quercetin and pectin, a complex of vitamins and minerals in combination with hygiene means for the oral cavity R.O.C.S. effectively prevented the negative effects of cariogenic diet and nitrates.
\end{abstract}

Conclusion. The effectiveness of the preventive complex for leveling adverse cariogenic effects has been confirmed in experimental conditions.

KEY WORDS: caries; puberty; prevention; biochemical markers.

Отримано 26.05.20

Адреса для листування: О. А. Макаренко, Інститут стоматології НАМН України, вул. Рішельєвська, 11, Одеса, 65026, Україна, e-mail: flavan.ua@gmail.com. 